Research, part of a Special Feature on Do we need new management paradigms to achieve sustainability in tropical forests?

\title{
Domestic Forests: A New Paradigm for Integrating Local Communities' Forestry into Tropical Forest Science
}

\author{
$\underline{\text { Geneviève Michon }}^{1}, \underline{\text { Hubert de Foresta }}^{2}, \underline{\text { Patrice Levang }}^{3}$, and Francois Verdeaux $^{1}$
}

\begin{abstract}
Despite a long history of confrontation between forest agencies and forest people, "indigenous" or "local" practices are increasingly considered as a viable alternative of forest management. This paper is a synthesis derived from various long-term research programs carried out by the authors in Southeast Asia and Africa on forests managed by farmers. These researches looked at local practices and underlying science, including their social, political, and symbolic dimensions. They also addressed evolutionary trends and driving forces, as well as potential and limits for forest conservation and development, mitigation of deforestation, biodiversity conservation, and poverty alleviation in a context of global environmental, political, and social change. We discuss how forest management by local communities, contrary to the unified models of professional forest management, exhibits a high historical and geographical diversity. The analysis we draw from the various examples we studied reveals several invariants, which allows proposing the unifying paradigm of "domestic forest." The first universal feature concerns the local managers themselves, who are, in their vast majority, farmers. Management practices range from local interventions in the forest ecosystem, to more intensive types of forest culture, and ultimately to permanent forest plantation. But in all cases, forest management is closely integrated with agriculture. The second universal feature concerns the conceptual continuity of planted forests with the natural forest, in matters of vegetation's structure and composition as well as economic traits and ecosystem services. The resulting forest is uneven-aged, composed of several strata, harboring a large diversity of species, and producing a wide range of products, with timber seldom being the dominant one. The term "domestic forest" aims at highlighting the close relationship the domestication process establishes between a specific human group, including its elementary units, the "domestic units," and the forest, transformed and managed to fulfill the needs of that group. The domestic forest paradigm calls for the integration into forest science of a new concept of land management in which production and conservation are compatible, and in which there is no choice to be made between people and nature. It does not aim at contesting the value of conventional forest science, but it proposes domestic forests as a new scientific domain, for the combined benefit of forest science and of forest people. It does not contest the value of conventional forest management models, but pushes towards more equitable relations between forest agencies and farmers managing forest resources on their own lands.
\end{abstract}

Key Words: forest management paradigms; indigenous forest management; local forest management; tropical forestry.

\section{INTRODUCTION}

All over the tropics, forest people have developed forest management practices that have proven their efficiency and their sustainability in accommodating local users' needs and in maintaining a healthy and dynamic forest cover over centuries (Noble and Dirzo 1997, Küchli 1997, Boffa 1999, Wiersum
2004, Cairns 2007).

Despite a long history of confrontation between forest agencies and forest people, these indigenous or local practices are increasingly considered as a viable alternative of forest management. But to what extent has this acknowledgement changed the forestry paradigms? When the normative discourse 
on local forest management gives way to real management plans, these local forests are generally considered as being too secondary or too degraded to serve global conservation objectives or sustainable production goals. This discrepancy reflects the failure of most professional foresters, especially in developing countries, to admit that forests used and transformed by locals have a value of their own and that the social needs and values through which these forests were designed and shaped are legitimate and deserve consideration.

In spite of a strong move for more local participation in forest management in the tropics, why are these forests still neglected? Beyond their diversity, do they represent a comprehensive mode of forest management? If so, what are forest agencies losing by ignoring this type of management? What can be done to integrate these forests into global forest development and conservation?

This paper is a synthesis derived from various longterm research programs carried out by the authors on forests managed by farmers in Indonesia and Laos from 1992 to 2005, and in Kenya, Tanzania, and Ethiopia from 1996 to 2007. These researches involved multidisciplinary teamwork in ethnobotany and ethnoecology, anthropology, economics, ecology, and botany. They looked at local forest construction practices and underlying science, including their social, political, and symbolic dimensions. They also addressed evolutionary trends and driving forces of the resulting forest systems, as well as potential and limits for forest conservation and development, mitigation of deforestation, biodiversity conservation, and poverty alleviation in a context of global environmental, political, and social change.

By pointing out the major elements of continuity and universality behind the high diversity of local forests, we define the concept of "domestic forest." We propose to adopt this concept as a new forest management paradigm. Beyond the common belief in social justice and equity of local forest management, beyond the common allegation that indigenous people are noble forest stewards, we suggest ways by which this domestic forest paradigm could help revisiting the global norms, standards, and methods of forest management. We conclude with the need for a redefinition of forest policies and regulations to accommodate this neglected but widespread aspect of forest management and to fully integrate its benefits for the society at large.

\section{WHICH AND WHOSE TROPICAL FOREST?}

Forests have not always been considered as a tract of wooded land. In the early Middle Ages in Europe, forests were defined as a legal category of resource management. The "foresta" or "silva forestis" progressively became a portion of land reserved for the privilege of the ruler (Bechmann 1990), thus having little to do with nature or ecology. The preservation and management of high forests soon became a concern to European monarchies, as forests were the favorite hunting grounds of the aristocracy, and were essential for the building of naval fleets. An edict of 1291 by Philippe le Bel mentions for the first time the existence of "masters of waters and forests" (Pardé 1986). The mission devoted to these forerunners of modern forest agencies was clear: to preserve the forest and its sustainable use for the benefit of its owner. This legal origin of the concept of forest, instituted as a particular domain, fuelled a forestry ideology in which the perpetuation of the existing forest, in composition as well as in structure, often became a dogma (Guillard 1999), resulting in the exclusion of farmlands, peasants, and local tree management practices. Local farmers were considered as the enemies of the forest and agriculture as a rival of forestry (Westoby 1979). This perception was transferred through colonial regimes to most tropical countries (Buttoud 1995, Barton 2002, Guizol and Ndikumagenge 2004, Pretzsch 2005), where it has been maintained up to now, especially in areas where agricultural land is still gained to the detriment of the forest. In the tropics, forest agencies still consider that forests should be managed exclusively by professionals under a comprehensive legal, administrative, and technical regulatory framework (Dove 1992, Fay and Michon 2005). Consequently, forest people are almost never considered as legitimate and knowledgeable forest managers.

Tropical forests present a unique combination of specific features:

- forest lands and resources are usually incorporated into a national, highly regulated forest domain administered by a national forest body. Millions of forest people are 
excluded from this domain. They are denied the ownership of the land and resources they depend on, and more often than not they are displaced, dispossessed, or marginalized (Repetto and Gillis 1988, Lynch and Talbott 1995);

- tropical forests are considered as a major source of valuable timber to be exploited and managed by forest concessionaires under the strict supervision of the forest administration (Smouts 2003);

- tropical forests also represent a unique ecosystem, hotspot of biodiversity, and exclusive habitat of many endangered plant and animal species (Mittermeier et al. 2000). A new kind of self-appointed legitimate forest manager has recently emerged: environmentalists and conservationists, active at the local level through the creation of parks and reserves, and at the global level through the development of international conventions;

- $\quad$ last but not least, tropical forests have been recently invested with a key role in the protection of the global environment against global warming, as potential carbon sinks, regulated and managed through global economic and financial instruments (Niesten 2002, Cramer et al. 2004).

From the feudal forests of the European Middle Ages to the tropical forest as a global environmental concern, two abiding features appear: the rejection of local rights on forests and their appropriation by outsiders (Westoby 1979, Ribot 2001, Barton 2002, Bon 2003, Pretzsch 2005). Visions, norms, standards, and practices related to local forest management are ignored, whereas the reality of the actual forest is not even acknowledged (Scott 1998). Though forestry, especially since the "Forests for People" World Forestry Congress held in 1978 in Jakarta, increasingly mentions the concern for sustaining the livelihoods of forest-dependant people, forests in the tropics are still managed for timber production, for watershed protection, for biodiversity conservation, or for carbon storage. This multidimensional aspect of tropical forest management in the name of "the public interest" is defined by specialists who most often do not even belong to the tropical world. However, beyond timber, soil erosion, biodiversity, and carbon, there is also a tangible forest, daily visited, harvested, and reshaped by farmers. This entity makes up a highly significant part of the forest matrix in the tropics (Boffa 1999, Gibson et al. 2000, Belcher et al.2005).

The attitude of professional foresters, environmentalists, and scientists from various disciplines toward local knowledge and forest-related practices is changing (Dove 1995, Valeix 1999). Central to this change is the need to incorporate the objectives of local evelopment and of poverty alleviation into forest management, but also the hope that local forest users could become the guardians of the forest (Forest Trends 2002). Though commendable, this shift has still to be coupled with the necessary changes in conceptual nd methodological tools (Hannam 2000, Mayers and Bass 2004, Kumar and Kant 2006, Temu et al. 2006). Participation is the uzzword, which is somehow revolutionary, given the centuries of imposed forest regimes. However, management defined a priori and pursuing exogenous objectives, e.g., biodiversity conservation, timber production, or environmental services, which seldom relate to ocal objectives (Dove 1995, Castro and Nielsen 2001, Sekhar and Jorgensen 2003). Foresters, environmentalists, and scientists always see local forests through the prism of an ideal, primary forest. If local forest management is praised, then existing local forests, whatever their structure and composition, are generally considered degraded, transitional, or secondary (Fairhead and Leach 1996). Contrary to timber concessions and forest reserves, local forests are not seen as a concrete and objective condition of the tropical forest, and are barely considered as resulting from a voluntary management system in which farmers' objectives and forest dynamics are complementary. There is not even a specific word to designate them. Are they local forests (Long and Nair 1999, Colfer and Byron 2001, Sherr et al. 2001), community forests (Bishop 1991, Arnold 1998, Wollenberg 2001, Kusel 2003), traditional forests (Hartshorn 1995, Kellman and Tackaberry 1997), sacred forests (Gadgil and Vartak 1976, Juhé-Beaulaton and Roussel 1998, Byers et al. 2001), peasant forests (Balent 1996, Ichikawa 1998, Cinotti and Normandin 2002), forest gardens (Wiersum 2004, Belcher et al. 2005), agroforests(Michon and de Foresta 1999), intermediate systems (Angelsen et al. 2000, Wiersum 2004)? Are they better characterized by the ethnicity of their managers: the Kayapo forest (Posey 1985), the Aka pygmies forest (Bahuchet 1985), the Ifugao forest (Conklin 1954)? This lack of proper terminology reflects a lack of conceptualization, and if nothing generic is said 
about these particular forests, they will indefinitely remain a nonconcept in forestry and forest management. But is conceptualization possible?

We propose to call these forests domestic forests. Domestic here does not refer to national, but to both the process of domestication and the relation to a household or to a group of households. The term domestic forest aims at highlighting the close relationship the domestication process establishes between a specific human group, including its elementary units, i.e., the domestic units, and the forest, transformed and managed to fulfill the needs of that group (Schlaifer 1997, Verdeaux 2003, Michon 2005).

\section{THE DOMESTIC FOREST AS AN OBJECTIVE CONDITION OF THE TROPICAL FOREST: FROM THE VISIBLE FORESTS TO SILVICULTURAL MODELS}

\section{What do domestic forests have in common?}

Domestic forests are site specific by nature. To be integrated into global forest management, some universal features must emerge from the various technical, structural, economic, and social dimensions of these forests.

The first universal feature concerns the local managers themselves. They are, in their vast majority, farmers. They secure their subsistence and income through production, be it of annual crops, animal husbandry, or tree crops. Forest management is one obvious component of their farming system, and we could therefore talk of "farmers" forest."

As an object, the domestic forest can be defined as the sum of the different forest ecological units that co-exist in a given landscape. These units are derived from natural forests through various practices including selective clearing as well as slashing and burning, discrete protection of native forest species, as well as plantation of native or introduced species, monitoring, or manipulation of natural production processes, as well as deliberate intervention in natural cycles.

Let us first elaborate on the visible forest and show how general silvicultural patterns and models can be drawn from the multiple existing examples (Michon and de Foresta 1999, Wiersum 2004).

\section{The visible forest and related silvicultural models}

A whole range of management practices aims at intervening locally in the forest ecosystem to favor particular species. These practices are highly localized and integrated within the existing forest matrix. They can involve slashing bushes or liana around valued species, opening the canopy or fostering shade, thinning out clumping species, or deliberately planting seedlings or wildlings in suitable locations. There are various degrees in management intensity, in practices, and in visible impacts. The resulting forest can bear only transient signs of human activity, such as the relatively high density of yams in the Pygmies' forests in Cameroon (Dounias 1996), or of fruit trees in the Kubu's forests in Sumatra (Sandbukt 1982). It can also appear as spots of modified vegetation in a matrix of more or less undisturbed forest. The most famous example is the Euterpe palm forests of the Amazon estuary, which are managed for the production of juice and palm heart (Anderson 1988, Emperaire 1997). The same process exists in Southeast Asia for the sago palm, Metroxylon sagu (Barrau 1959). Other examples include the creation of Brazil nut groves in Amazonia (Lescure 1995), and of fruit tree groves in mainland Borneo (Seibert 1989). In Laos, forests are managed for cardamom production (Aubertin 2000, Foppes and Ketphanh 2000), in northern Thailand for miang tea production (Watanabe et al., 1990), in central Borneo for rattan production (Godoy and Feaw 1989, GarcíaFernández 2001), in southwest Ethiopia for coffee and spice production (Senbeta and Denich 2006), etc.

However, more intensive types of forest culture can also be found. These involve a cultivated phase purposely integrated and maintained within the forest matrix, showing greater and longer-term interactions between human efforts and natural forest cycles. In the example of benzoin cultivation developed by Batak Toba people in North Sumatra (Watanabe et al. 1990, García-Fernández et al. 2003), the silvicultural pattern integrates a mediumterm phase of forest production into a global continuum of old and successional forest. Benzoin tree (Styrax benzoin), a medium-sized tree producing a fragrant resin, is introduced as seedlings in the undergrowth of a patch of pristine mountain forest. As benzoin develops, canopy trees and other undergrowth species are selectively cut, so that the manipulated forest turns into a benzoin garden. As 
long as trees are tapped from year 10 to 40, the garden is more or less carefully maintained. It is then gradually abandoned and reverts to a typical successional forest. Several decades later, the forest can eventually be reused for benzoin production (Figs 1 and 2).

In other cases, the integration of planted trees leads to a permanent agroforestry system: in high elevation areas of southern Ethiopia for instance, many coffee agroforests (Fig. 3) result from the replacement of the undergrowth of natural forests by coffee trees, planted along with other useful crops such as Ensete ventricosa, whereas most trees of the natural forest canopy are conserved (Abebe 2005). The same kind of coffee agroforest system has been developed in Karnataka, India (Depommier 2003).

Another example of domestic forest, certainly the largest in terms of area covered, is directly linked to food crop production. It consists of the various stages of regrowth or forest fallows linked to the swidden cultivation cycle. Unlike the management models presented above, the original forest ecosystem is more-or-less completely removed, and a new forest is allowed to regenerate. This forest is generally classified by biologists as degraded or secondary. For local farmers however, it is an integral and essential part of the swidden cultivation system (Conklin 1954, Colfer et al. 1997, Levang et al. 1997). Many of these forest fallows are actually enriched through plantation (Balee and Gely 1989, Cairns 2007) for fruit production, restoration of soil fertility or for hunting purposes. In some cases, the swidden is totally planted with trees, and the fallow becomes the main component of the swidden cultivation cycle, as in the numerous examples of rotational forest plantations in Indonesia (Michon and de Foresta 1999). In Kalimantan for instance, rattan is intercropped with upland rice in the swiddens, and grows up in the regenerating forest, along with spontaneous fallow trees. Rattan can be harvested from $8 \mathrm{yr}$ after planting, and produces for the following 20 to $35 \mathrm{yr}$. The rattan garden is then recycled through slashing and burning for a new rice-and-rattan succession. Except for its exceptionally high density of rattan and other useful species, it structurally resembles a dense, naturally regenerated secondary forest (Fried 2000, GarcíaFernández 2001). In the lowlands of Sumatra and Kalimantan, rubber gardens, also known as rubber agroforests, constitute another outstanding example of rotational forest production (Gouyon et al. 1993, Dove 1993, 1994) with cycles ranging from 40 to
70 yr (Fig. 4). Due to these long cycles, combined with tending practices that encourage enrichment planting, rubber gardens harbor a considerable number of plant species. This half-managed richness allows for the provision of plant foods and material, timber, and game (Fig. 5), and these compensate, at least partly, for a lower latex productivity. Beside this economic importance for farmers, rubber gardens play a determining role in the conservation of plant and animal biodiversity in the lowlands. This role is dramatically increasing with the present depletion of the last unlogged dipterocarp forests (de Foresta 1992).

Last but not least are the domestic forests consisting of permanent forest plantation (Michon and de Foresta 1999). As the aforementioned rotational forest model, these forests arise from the slashing and burning of the original forest ecosystem, with tree seedlings planted within the swidden. They evolve through gradual forest reconstruction involving plantation, protection, selection, and facilitation of the natural regeneration processes. Once developed, the planted forest will reproduce itself without disruption in structural or functional patterns, thanks to a balanced combination of anticipated replacement of decaying individuals, mimetic gap planting, and respect of natural dynamics, which all allow further diversification through the colonization of many forest species among the cultivated stand. After several decades, the forest plantation is structurally close to an old secondary forest, with the restoration of the global ecological features of a diversified forest ecosystem. Some very interesting models of integral forest plantation have been described in Indonesia (Torquebiau 1984, Sardjono 1992, Aumeeruddy 1993, Momberg 1993, Padoch and Peters 1993, Sundawati 1993, de Jong 1994, Salafsky 1994, Michon and de Foresta 1999). The Damar agroforests (Michon et al. 2000), developed in the south of Sumatra since the beginning of the 20th century for resin production, nowadays cover some tens of thousands of hectares. Like natural forests, they are characterized by a high canopy, dense undergrowth, high levels of biodiversity, and a perennial structure (Figs 6 and 7).

Outside Indonesia, without trying to be exhaustive, such a model encompasses the coffee agroforests and the cocoa agroforests in Central and South America (Somarriba et al. 2004, Schroth et al. $2004 a$ ), the rubber agroforests in Amazonia (Schroth et al. 2004b), the home gardens of Kerala 
Fig. 1. The benzoin forest establishment and cycle in North Sumatra, Indonesia.

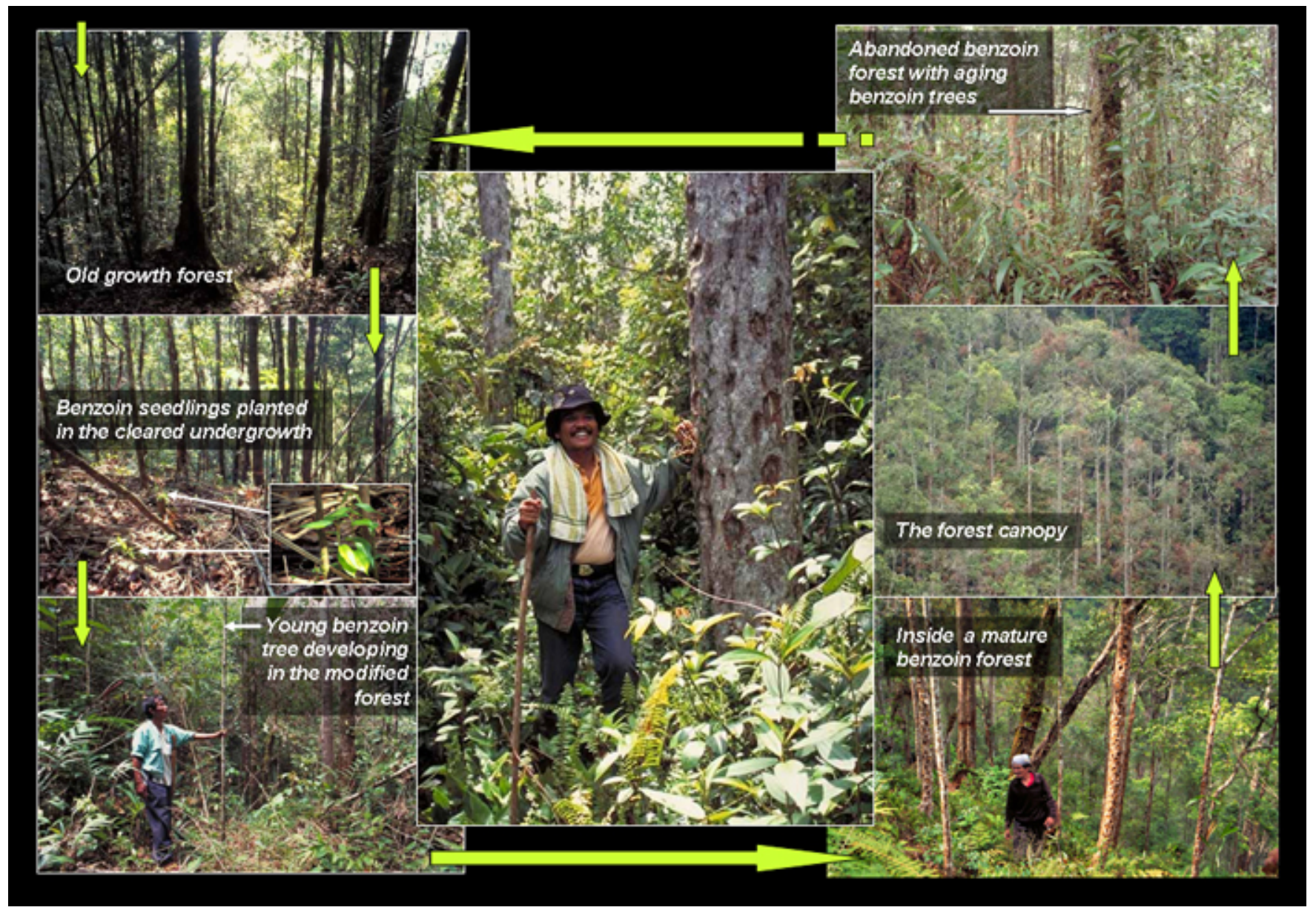

in India (Depommier 2003), the coconut-based agroforests in the Pacific islands (Lamanda et al. 2006), the Chagga home gardens on Mount Kilimanjaro (Fernandez et al. 1984, Verdeaux 2003), the village groves of forest-savanna mosaic in Guinea (Fairhead and Leach 1996), oil palm groves in central and West Africa (Dupire and Boutiller 1958, Raison 1988), or cocoa growing under forest canopy in Ivory Coast (Rougerie 1957, Gastellu 1980, Léonard and Oswald 1996) and Cameroon (Dounias 2000) where even the most intensive cocoa plantations are increasingly shifting away from monoculture toward a more mixed system. Agroforestry parklands, though exhibiting different structures in relation to a dryer climate, are equivalent in their principles to these agroforests of the humid tropics. They encompass the Khejri system based on Prosopis cineraria in Rajahstan, India (Depommier 2003), but also all the numerous facets encountered in sub-Saharan Africa, where néré (Parkia biglobosa), karité (Vitellaria paradoxa), baobab (Adansonia digitata) and Faidherbia albida, along with many other species are favored, planted, and managed by local farmers, perfectly integrating agriculture and forestry (Pélissier 1964, Seignobos 1982, Raison 1988, Boffa 1999).

All these silvicultural models are not exclusive in the sense that they usually coexist with others in a single location; the domestic forest being composed of a mosaic of different units that may be related to one or another of the above models. 
Fig. 2. Harvesting and sorting benzoin resin.

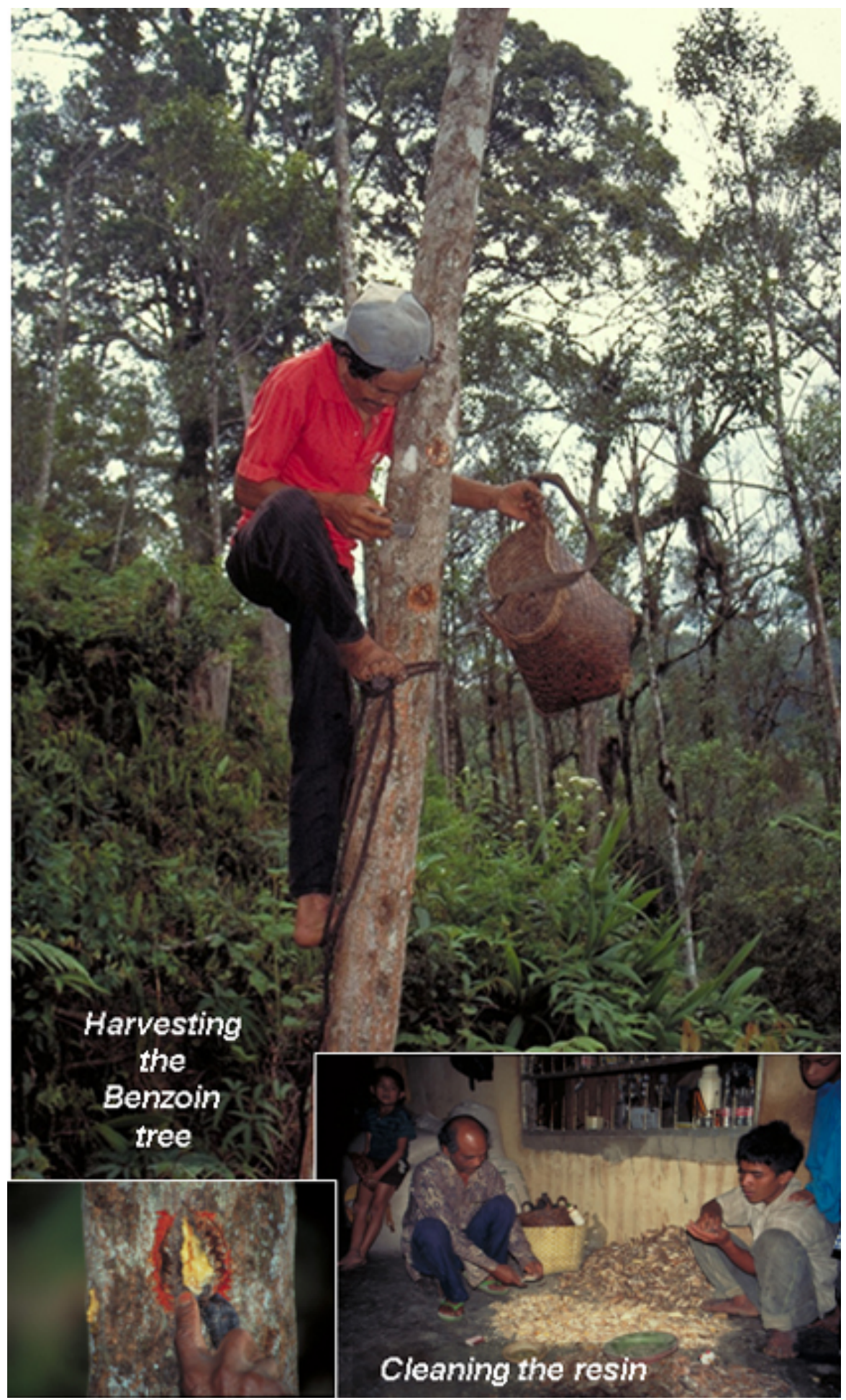


Fig. 3. A coffee forest in Ethiopia, evolved directly from the natural forest.

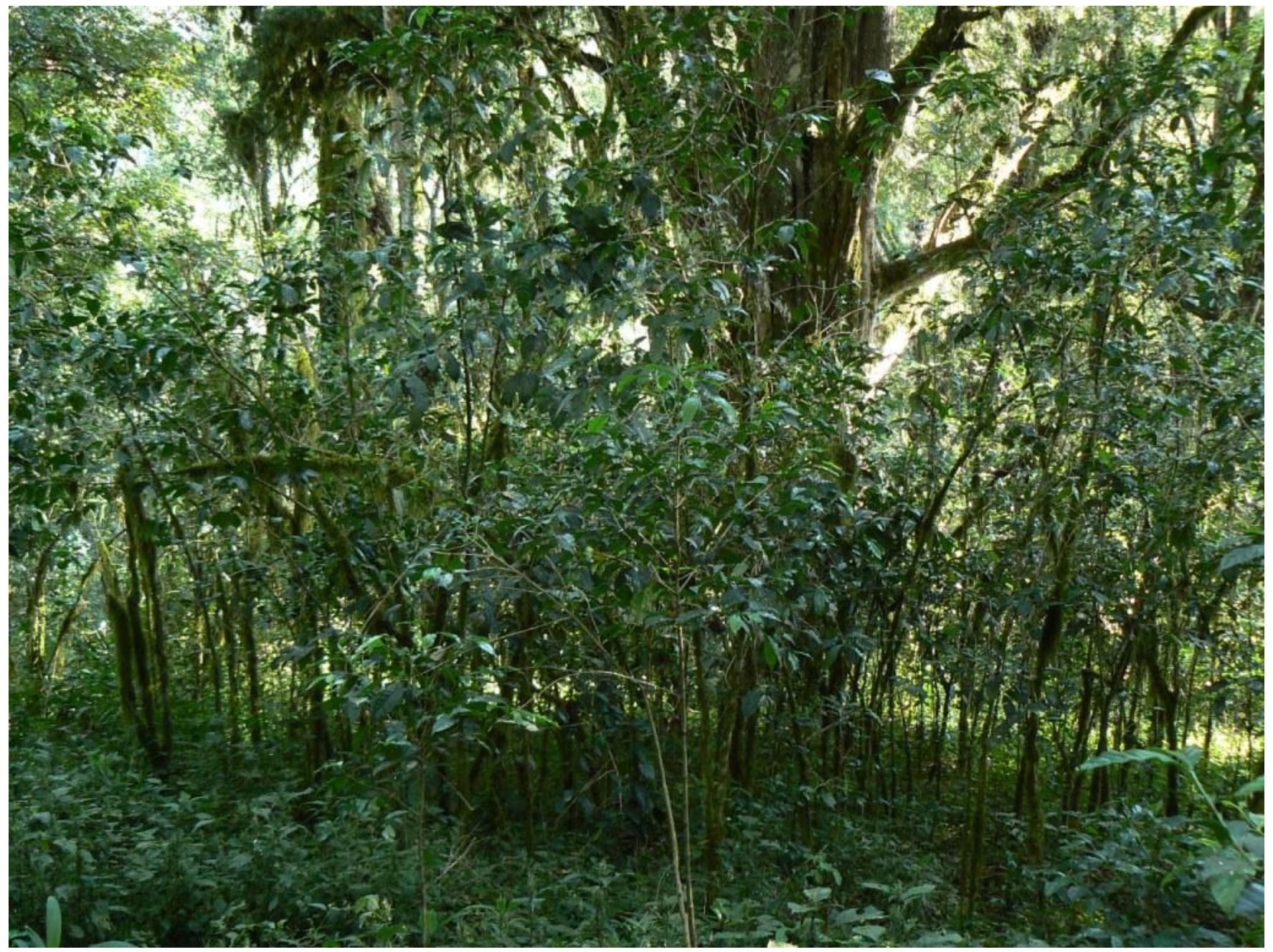

\section{FROM THE OBJECT TO THE CONCEPT: FOREST DOMESTICATION AND THE UNIVERSAL FEATURES OF DOMESTIC FORESTS}

The various domestic forest facets exposed above reveal two major underlying principles that are lacking in conventional silviculture: a close integration with agriculture, and a conceptual continuity of planted forests with the natural forest.

\section{A close integration with agriculture}

Professional forestry developed first through fencing in the forest to protect it from farmers (Rietbergen 2001). On the contrary, the domestic forest did develop and succeed precisely because of its close articulation with swidden cultivation. The practice of fallowing plays here a catalytic role for the establishment and development of the forest, whereas the dynamics of cyclic production supports its long-term maintenance and reproduction, not to mention economic and social complementarities. Beyond this technical and socioeconomic articulation, there is also a real symbiosis between 
Fig. 4. The rubber forest establishment and cycle in Sumatra and Kalimantan, Indonesia.

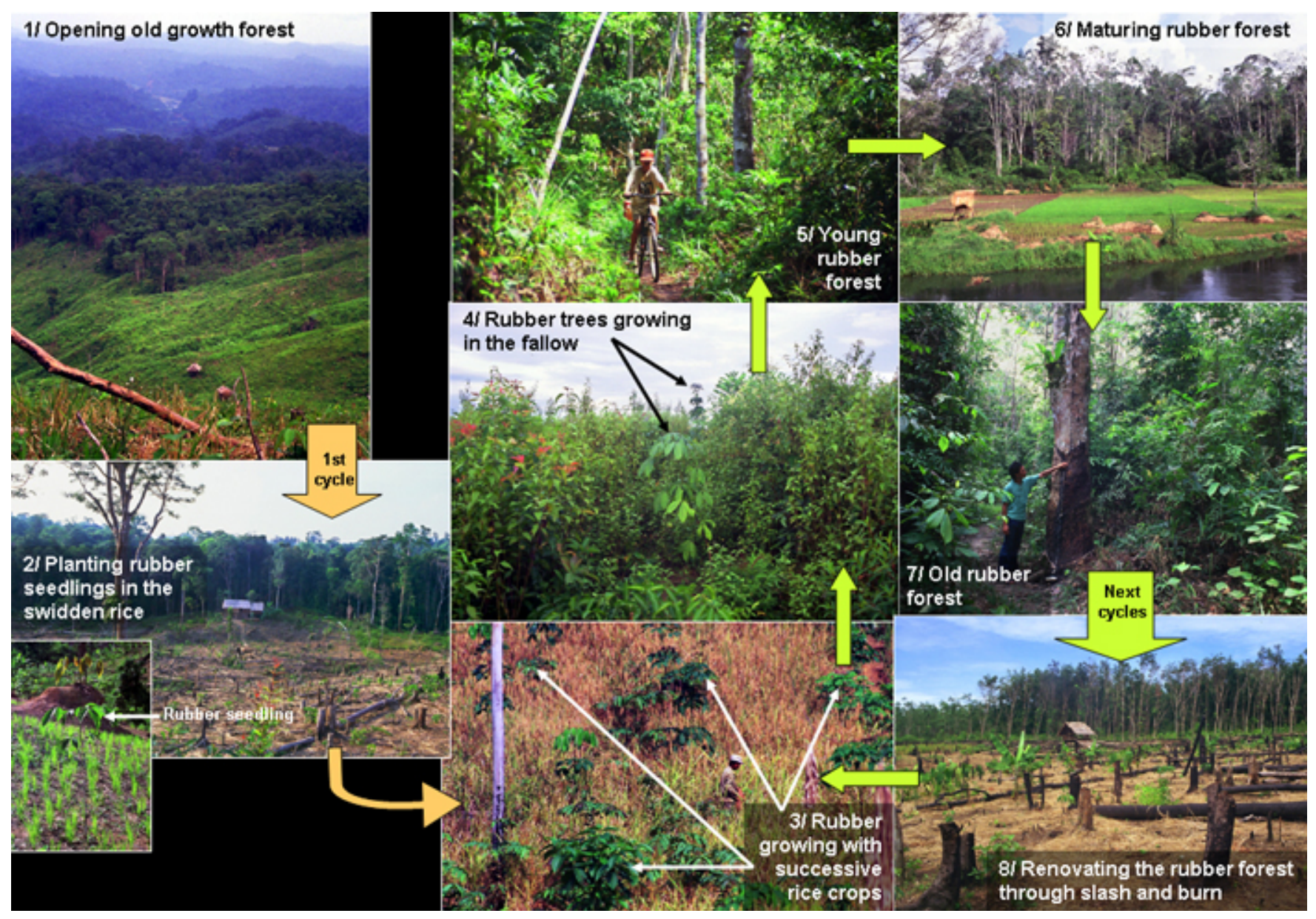

swidden cultivation and domestic forest management. Agricultural and forest-related practices are coevolving and this coevolution is usually positive for both sides, as it has facilitated the emergence of a profitable forest culture and has in turn deeply changed the dynamics of swidden agriculture (Dove 1993, Levang et al. 1997).

Foresters have often denied that forest plantations can be profitable at the smallholder's scale in the tropics (Dove 1992, Evans 1992). Domestic forests do prove the contrary. The estimated $2 \times 10^{6}$ ha of rubber agroforests, and 50,000 ha of Damar agroforests in Sumatra are brilliant examples of smallholder's success in forest culture (Michon et de Foresta 1999). The swidden has been central to this success. In return, the development of the planted forest has allowed a quick intensification of swidden agriculture. The introduction of forest culture increases labor productivity as well as the global productivity of the whole farming system. Unlike traditional fallows, planted forests provide cash and other economic resources, without major constraints on land and labor. This intensification is achieved by a smooth adaptation of practices, without any painful crisis or profound change in the farming system. This has important social consequences, as it avoids the marginalization and impoverishment of a whole class of farmers. Moreover, it allows securing land appropriation and capital accumulation, a patrimony that can be transferred to the next generation (Michon et al. 2000, Suyanto et al. 2001). In this sense, it constitutes the very sustainable basis of the 
Fig. 5. Various facieses and products from the rubber forest.

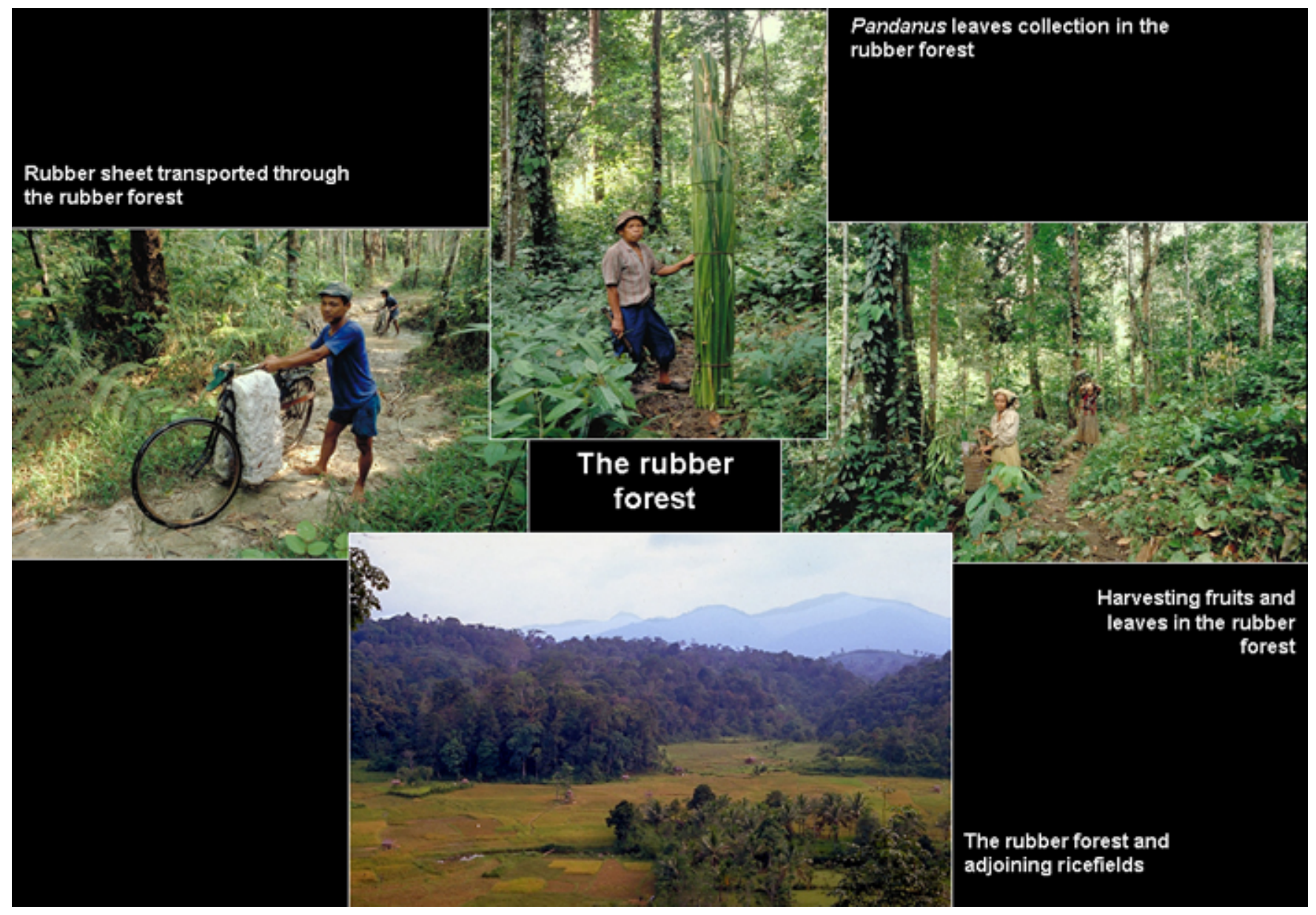

foundation of the domestic group. The large areas covered with agroforestry parklands in sub-Saharan Africa, which sustain the livelihood of millions, constitute a similar example of the silvicultural success of local farmers in the drier regions of the Tropics (Sheperd et al. 1993, Boffa 1999, Bodin et al. 2006).

\section{The "forest preference": a clear continuity between domestic forest and natural forest}

Professional foresters often stress that the only way to rationalize costs and maximize benefits in modern forestry, as in modern agriculture, relies on an artificial simplification of structures, and that tree crop diversity, if technically feasible, is not economically desirable (Evans 1992, Wormald
1992). In the tropics, this productivist approach has induced a clear dissociation between forest plantations and natural forests. Plantations deal mainly with short-lived tree species (Acacia, Eucalyptus, Gmelina), quick rotations, and a single output: timber. They are conceptually as well as spatially and temporally disconnected from natural forests. On the contrary, domestic forest culture has succeeded precisely because of its conceptual continuity with the natural forest, expressed in ecological as well as economic terms. This silviculture strategy that emphasizes diversity of products and heterogeneity in vegetation, and that respects or restores global forest structures, functions, and services over space and time is what we have called "forest preference" (Michon and de Foresta 1999). 
Fig. 6. The damar forest establishment and development in Lampung, Sumatra, Indonesia.

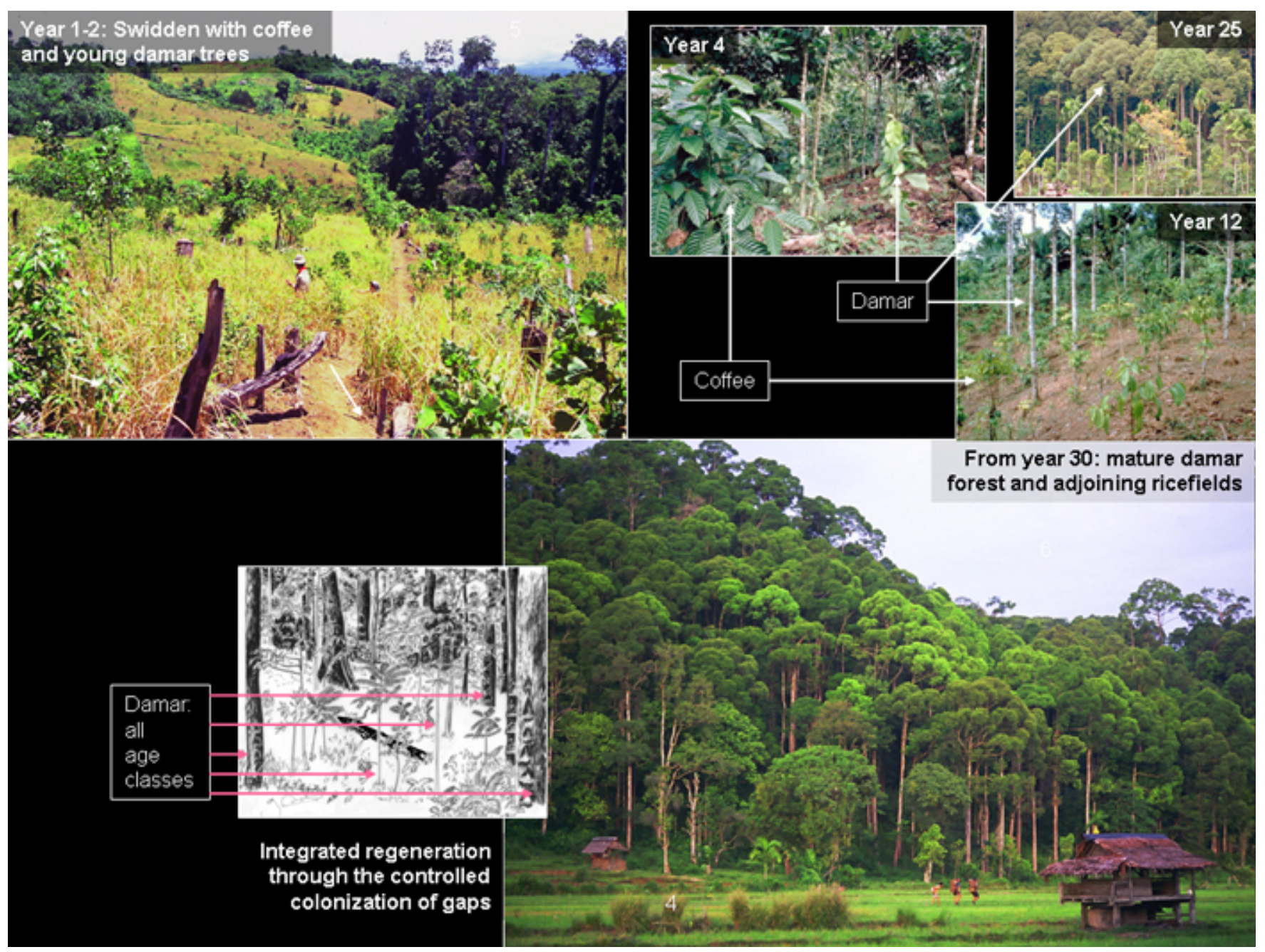

Forest preference incorporates the notion of ecosystem management, a management that targets not a single species, but a manipulated ecosystem. By introducing a cultivated forest crop in the natural dynamic processes at a small or large scale, farmers practice a forest culture that, contrary to what happens in conventional monocrop plantations, becomes part of the structure and of the functioning of the forestland ecosystem. This forest preference leads to the restoration of diversified and autonomous biological structures mimicking the original habitat (Fig. 8), which allows the environmental services of the original forest to be sustained, including soil protection, regulation of water flows, and conservation of high levels of biodiversity (Fig. 9) (Michon and de Foresta 1995, Garcia 2001, Garcia et al. 2003).

Forest preference also incorporates the idea of ecosystem development. Through the manipulation of the silvigenetic processes and through a high degree of mimicry of natural succession patterns, farmers can extend the life of a forest plantation over indefinite periods. The established forest grows and diversifies, and is able to produce and regenerate over the long run with minimal input. The forest preference therefore constitutes the ecological foundation of short- and long-term flexibility and 
Fig. 7. Various facieses and products from the damar forest.

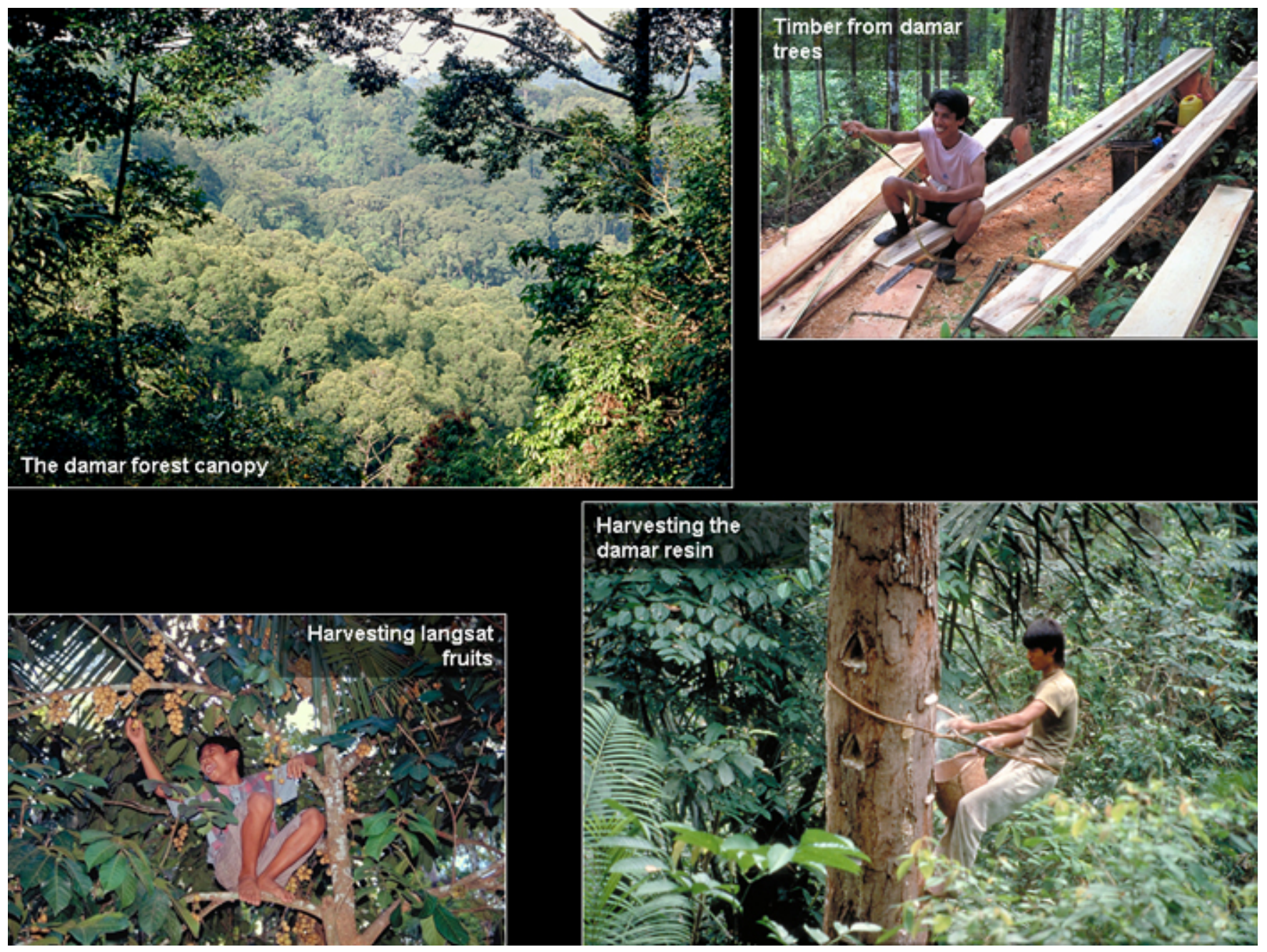

reversibility, but also of multifunctionality, which are nowadays considered as the three fundamental qualities of any sustainable resource management.

This strategy, targeting the ecosystem, allows us to question the domestication process underlying this forest construction. The construction of the domestic forest involves technical and biological processes of vegetation manipulation that clearly result in the domestication of individual plant species. But we can also conceptualize this construction as a process of forest domestication in which trees are manipulated for production improvement while maintaining their adaptation to a diversified forest ecosystem, and trying to channel forest production through an optimized ecological model (Michon and de Foresta 1997). Far from the ecological oversimplification associated with modern agriculture or even tree culture, this process of domestication emphasizes diversity and complexity.

\section{FOREST DOMESTICATION: THE INTANGIBLE DIMENSIONS}

Models and concepts related to forest management do not deal only with techniques, but also with 
Fig. 8. A sketch-profile drawn from a fruit forest in West Sumatra, Indonesia showing the complex, forest-like structure of the vegetation.

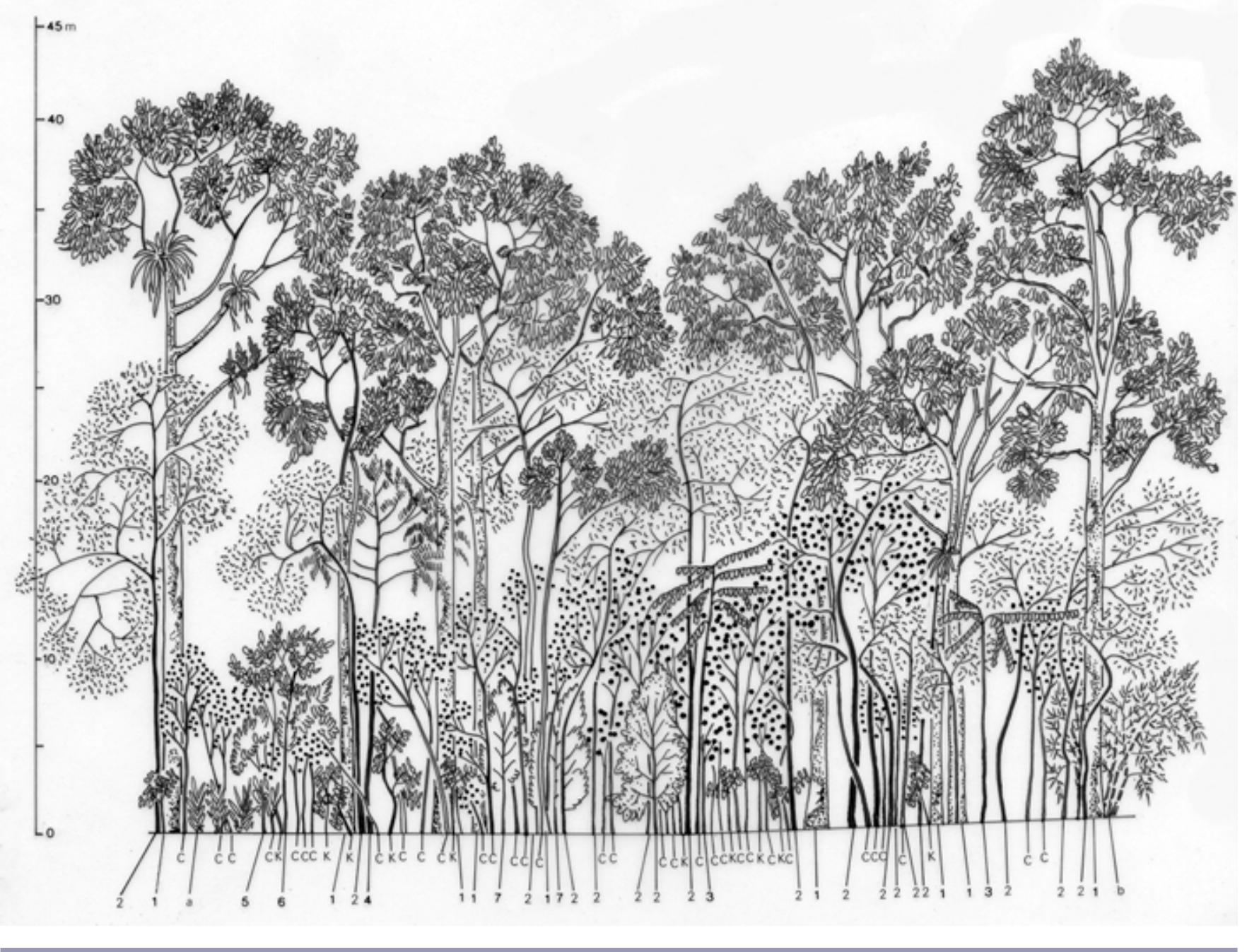

ideologies and representations, with economic strategies and socio-political relationships within and between human groups. The forests we see constitute the visible part of a larger space, which is altogether material, economic, mental, social, and political.

\section{Defining the relationship between people and natural components}

The material forest structure and the immaterial appropriation process are intimately and actively linked (Godelier 1986). The reproduction of the former cannot be dissociated from that of the latter. Beliefs and religion, myths, and history define how forest elements, e.g., plants, animals, streams, springs, caves, etc., relate to the human world, to the group and to the domestic units. The way humanity, kinship and domesticity are vested in the forest is specific to each local group, but the mental process that sustains it follows universal patterns: forest domestication always includes defining which elements of the forest relate, or not, to the human group, which kind of relation every category of this group establishes with these elements, and 
Fig. 9. Natural forest (left, Borneo), domestic forest (upper right, fruit forest, Sumatra), and monocrop forest plantation (lower right, Eucalyptus, Congo) confronted: if biodiversity levels in domestic forests are not as high as in natural forests, they are much higher than in monocrop forest plantations.

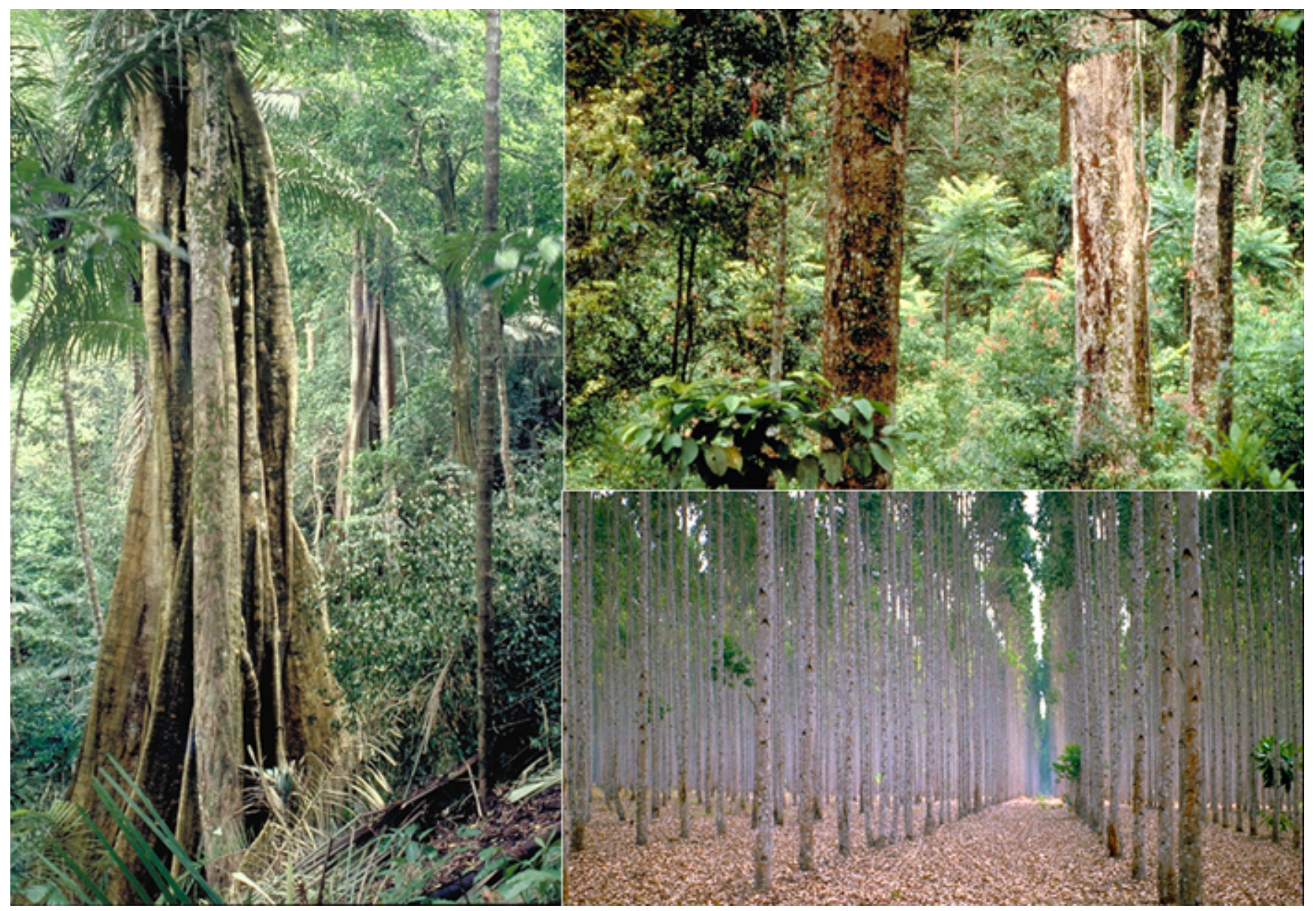

why it is so (Descola 1987, Brunois 2004). The Achuar people of the Amazon, for instance, exemplify how human societies may include in their cultural universe elements that modern thinking usually considers as natural and totally apart from humans. Forest socialization by the Achuar is thought as a relationship system organized at the domestic unit level and totally isomorphic with the one used for humans within that unit: forest animals and plants are considered as father, son, or brother in law and symbolically treated as such by their human partner (Descola 1987). More broadly, this symbolic domestication sets the principles that define how the group and its elementary units will interact with forest elements. Forest domestication sometimes just consists in this symbolic process, but most often this process precedes the more tangible domestication for which it serves as a foundation and an organizational principle. This clearly contrasts with the principles orienting professional forest management, in which nature is considered as an object external to the social, religious or political spheres and treated according to technical norms considered as neutral. 


\section{Defining the social organization of forest use}

Furthermore, material and immaterial forest domestication is closely related to the social structure of production. The immaterial domestication of the forest creates a double bond: to the whole social group as well as to the domestic units. This shaping of the forest-related social relationship, which does not define the relation between forest objects and people, but social and political relationship between people themselves regarding forest-related matters involves the definition of access principles and resulting property rights, consisting in formal and nonformal norms, rules, and regulations (Weber et al. 1990, Michon and de Foresta 1999, Gibson et al. 2000). It specifies who is allowed to do what in which part of the forest, or with which resource. It can be framed by religious, kinship, class, or other internal socio-political logics. But it always refers to the above-mentioned symbolic domestication: how and why the group and its elementary units define their relation with forest elements. Its modalities are again specific to every local group, but they present a number of commonalities:

- Socially, forest domestication is always defined by the group at the group's level, even when it incorporates norms or rules developed at extra-local levels. It is acknowledged and respected by all the members of the group (Michon et al. 2000, Verdeaux 2003). This comes in contrast with the various models of community forestry and other types of devolution processes to local groups, brought from outside with imported visions of forest, community, and management;

- The rights system often achieves an integrated balance between the rights and needs of the domestic units and those of the whole group. The practices that shape the forest logically induce long-term rights to users, which ensure the long-term reproduction of the forest units while consolidating that of related domestic units. But these rights are bound by collective institutions and rules aimed at ensuring the long-term maintenance of the whole forest system as a basis for the social reproduction of the whole group (Peluso 1996, Michon 2005). These rules specify that property rights on forest land and resources are inalienable outside the group, and set the social norms for inter-generational transmission;
- The association between local and collective rights results in the piling up of social spaces in the forest. As a result, the appropriation regime is neither private nor common property. At plot level, forest resources are owned and managed primarily by one domestic unit for specific purposes, but other units, or specific groups of people in the community, may have different rights on the same space, regarding the same, or different, resources (Michon et al. 2000, Bouamrane and Michon 2004). This piling up may fade away in planted forests where land itself has become a major resource, but the multipleuse/multiple-users aspect persists for secondary resources.

\section{Forest domestication for the maintenance of social units}

The domesticated forest is mainly targeted at sustaining the livelihood of elementary units. This first function is achieved through the provision of subsistence and cash benefits for consumption or distribution. Forest plots are always an important element in household economics. They are commonly associated to other productive activities and contribute to their economic reproduction. As a transferable patrimony, the appropriated forest resources also represent the material and symbolic foundation of domestic units, and the necessary condition of their social reproduction. In the same way, the whole forest system, even when divided into individual plots, constitutes the indivisible material and symbolic foundation of the group and helps preserving broader interests. As it embodies the group's social relationship system, it is essential to its cohesion and durability. Forest domestication therefore links the biological sustainability of a forest-based productive system to both the reproduction of the social system and to the economic sustainability of the embedded domestic units. Creating and maintaining this link is not usually the concern of conventional forest management. In the same way, the organic bond between individual and collective action and interests contrasts with the divide between the individual/private and the collective/public spheres that often characterizes conventional forestry. 


\section{Forest domestication as an arena of socio- political relationship between human groups}

Forest domestication is closely related to the construction of the relationship of the local group with outsiders. It creates modified forest structures grounded in delineated spaces that can easily be recognized by outsiders, and that are associated with easy to express property rights and other locally specific social attributes. It therefore represents a major contribution in the definition and the perpetuation of a territory: a portion of appropriated land belonging to a specific group, which is acknowledged by neighboring groups.

This notion of permanent territory is inseparable from the notion of identity. Identity reinforces the emergence, the validation, or the reproduction of the territory. Because the domestic forest constitutes the economic and social foundation of the domestic units, forest domestication represents a major element in defining the identity of the whole group, through a double bond: the forest is appropriated, and therefore belongs to the group and is part of its own history, but in the same time, the group has a strong sense of belonging to that particular forest, i.e., it is part of the natural history of that forest.

However physically and socially rooted these domestic forests may be, their very existence is generally denied by global political institutions who neither consider domestic forests as a legitimate and appropriated territory nor as a valuable land-use system. This lack of acknowledgement constitutes a permanent feature, both through history and countries.

\section{DOMESTIC FORESTS: A CHALLENGE FOR THE FUTURE?}

Our studies on the evolution of domestic forests in Indonesia (Angelsen et al. 2000), as well as related studies in Africa and Southeast Asia (Verdeaux 1999, Asbjørnsen et al. 2004) have illustrated how the construction, development, or collapse of domestic forests is often related to the power relationship between local groups and politically dominant institutions. Other studies (Dounias 2000, Ruf 2001) have shown the evolution from monocrop plantations to agroforests and domestic forests, due to technical and economic factors. Our recent observations in Indonesia show an opposite evolution. In the present context of decentralization and strong influence of globalization, particularly with the increasing demand of China for raw material, e.g., rubber, palm oil, domestic forests tend to evolve into monocrop plantations. Recently in Sumatra there has been a clear tendency among smallholders to replace old rubber agroforests by pure rubber plantations and even by oil palm plantations (Ekadinata and Vincent 2005). Whereas teak has been introduced on all farmlands in Lampung, isolated or on borders first, sometimes as a single crop on the whole plots, damar agroforest owners often consider selling their damar trees as timber to recently established local sawmills. Nowadays many families benefit from regular income deriving from off-farm activities. Often, farming is no longer considered for subsistence but as a source of additional cash income. The most favored opportunities are those that secure the land holding, need little labour and supervision, and provide high returns. Monocrop tree plantations supply these services better than domestic forests. This trend has also been recently observed in Borneo (Potter 2001, 2004) and Java (Parikesit et al. 2004). In this era of agrarian transition, with strong economic as well as political incentives for a new development of smallholders' plantation crops for biofuels or for carbon storage, domestic forests are not disappearing but changing, and it might be too soon to foresee their future.

\section{CONCLUSION: ACKNOWLEDGING THE "DOMESTIC FOREST" AS A NEW PARADIGM}

The process of forest domestication by local groups, through its combined material and immaterial dimensions, results in the creation of a particular forest space structured by both the whole group and its domestic units. This forest space supports altogether local livelihoods, culture, and sociopolitical relationships both within the group and with the outside world. Although the resulting forest systems range from punctual management of wild resources to entirely reconstructed forest ecosystems, this space, that we have called domestic forest, can be analyzed as a comprehensive model exhibiting invariant features.

The domestic forest constitutes a specific category of forest management which clearly differs from classic or more modern professional forestry as exposed in textbooks such as Pancel 1993, or more recently Higman et al. 2005) in terms of physical 
and physiognomic components, of functions and benefits, of techniques, rationale and management objectives. The domestic forest is neither a production nor a conservation forest, and not even a forest management model that embodies multifunctionality. It is "a forest for living," a forest that integrates production and conservation with social, political, and spiritual dimensions. It clearly constitutes a "third way" in global forest management.

The domestic forest is thus proposed as a unifying paradigm that points to the specificity of forest management by local users in the context of tropical forestry. This paradigm can help revisit forest management in general, and more precisely the way forest development accommodates forest people. Even though local participation is praised and local knowledge recognized, the shift toward giving a real place to domestic forests in forest development is far from being accomplished. More often than not, local knowledge is reduced to a few simple blueprint techniques. Real community-based forest development remains an empty box, especially in the humid tropics. In the dryer tropics, the forecasted fuel wood crisis probably urged the foresters to be more receptive to local peoples' forest management practices (Sheperd et al. 1993). The acknowledgement of domestic forests not only calls for a revision of the normative, conceptual, and technical frameworks of forestry, but it also requires deep changes in the political, legal, and regulatory frameworks (Fay and Michon 2005). Official designations of forest areas not only ignore the existence, the originality, the legitimacy and the benefits of domestic forests, but forest regulatory frameworks most often discriminate against forest product management and tree growing by farmers. Current official definitions of planted forest are geared toward industrial monocrop plantation and deliberately leave little room for farmer-created forests and agroforests. Furthermore, over-regulation imposed on forest products restricts access to markets for farmergrown timber and tree products.

That forestry should be helpful to rural people has been recognized long ago by foresters. Since 1978 and the World Forestry Congress, social forestry programs have developed everywhere and are shown as proofs that forestry now cares for the rural people (Dove 1995). But these programs have been added to other forestry programs with no major change in the organization and functioning of forest agencies, as if all programs were of the same nature. Very few took into account the specificities forestry is confronted with in supporting rural peoples' livelihoods. Such specificities were recognized by a handful of enlightened foresters such as Jack Westoby who, in his opening address to the 8th World Forestry Congress in 1978, insisted that agriculture-supportive forestry activities "are activities that cannot be carried out on the required scale and in the required manner by a conventionally oriented and a conventionally organized forest service" (Westoby 1979). Westoby could not go further in 1978. But $30 \mathrm{yr}$ later, thanks to the numerous studies on local forests managed by rural people all over the tropics, we can go further and stress the need for tropical forestry to acknowledge the domestic forest paradigm and to adopt this paradigm as a basis for forestry development in a rural context.

The domestic forest paradigm does not aim at contesting the value of conventional forest management models, i.e., forest for production and forest for conservation, but it pushes towards more equitable relations between the administration in charge of forest management and farmers managing forest resources on their own lands. In areas where smallholders represent the main actors in resource management and where natural forests have been converted into domestic forests by an agricultural dynamics, production forest and conservation forest models are inadequate and cannot be implemented. The current exclusive domination of these models in forest management hampers the ability of domestic forests to further develop and provide their benefits. Adopting this new paradigm would be the best way to reverse the past and current trend that sees many concrete examples of domestic forest collapse due to disincentives, and sometimes to continuous harassment from the institutional environment.

It does not aim either at contesting the value of conventional forest science, but it pushes toward integrating domestic forests as a new scientific domain, for the benefit of forest science, but also for the benefit of forest people: like most forests, domestic forests have problems of their own, where foresters could help through developing adapted research, technique and science. But foresters should understand that their involvement in domestic forests cannot be the same as in conventional forests. Here, to quote Westoby 
(1979), it can only be "to stimulate, offer guidance and suggestions, impart techniques and carry out training."

Finally, it should be clear that the domestic forest paradigm that we propose here not only addresses the renovation of the conventional forestry framework, but beyond that, the context of sustainable development itself. The domestic forest paradigm calls for a new concept of land management in which production and conservation are compatible, and in which there is no choice to be made between people and nature. This means much more than just forests.

Responses to this article can be read online at: http://www.ecologyandsociety.org/vol12/iss2/art1/responses/

\section{Acknowledgments:}

The authors want to thank the EU for the financial support to the FORRESASIA programme on domestic forests (1996-2001), as well as ICRAF (the World Agroforestry Center) and CIFOR (the Center for International Forest Research) for the material support and the research environment they provided to our successive projects between 1994 and 2005. We also want to thank colleagues who provided comments and remarks which greatly helped to improve the manuscript, with a special mention to the two anonymous referees for their valuable inputs and comments.

\section{LITERATURE CITED}

Abebe, T. 2005. Diversity in homegarden agroforestry systems in southern Ethiopia. Dissertation, Wageningen University, Wageningen, The Netherlands.

Anderson, A .B. 1988. Use and management of native forests dominated by açai palm (Euterpe oleracea mart.) in the Amazon estuary. Advances in Economic Botany 6:144-154.

Angelsen A., Asbjørnsen H., Belcher B., Michon G., and Ruiz-Perez M. 2000. Cultivating (in) Tropical Forests? The evolution and sustainability of intermediate systems between extractivism and plantations. In H. Asbjørnsen, A. Angelsen, B.
Belcher, G. Michon, M. Ruiz Pérez, and V. P. R. Wijesekara, editors. Proceedings of the International Workshop: Cultivating (in) Tropical Forests." (Lofoten, 2000). Lofoten, Norway.

Available online at: http://www.cefe.cnrs.fr/coev/pdf/ dounias/33.pdf.

Arnold, J. E. M. 1998. Managing forests as common property. Food and Agriculture Organization of the United Nations (FAO) Forestry Paper 136. Rome, Italy.

Asbjørnsen H., Angelsen A., Belcher B., Michon G., Ruiz Pérez M., and V. P. R. Wijesekara, editors. 2004. Proceedings of the International Workshop: Cultivating (in) Tropical Forests? The evolution and sustainability of systems of management between extractivism and plantations. European Tropical Forest Research Network Publication Series (Lofoten, 2000). Lofoten, Norway.

Aubertin, C. 2000. Intermediate systems: a concept for sustainable development? Case studies from Brazil and Laos. Paper presented at the International Workshop "Cultivating (in) tropical forests". Kræmmervika, Lofoten, Norway. Available online at: http://http://www.etfrn.org/etfrn/workshop/lofoten/ etfrn series 3.pdf.

Aumeeruddy, Y. 1993. Agroforêts et aires protégées. Représentations et pratiques agroforestières paysannes en périphérie du Parc National de Kerinci Seblat, Sumatra, Indonésie. Dissertation, Montpellier, France.

Bahuchet, S. 1986. Les Pygmées Aka et la forêt centrafricaine, ethnologie écologique. SELAF, Paris, France.

Balee, W., and A. Gély. 1989. Managed forest succession in Amazonia: The Ka'apor case. Pages 129-158 in D. Posey and W. Balee, editors. Resource management in Amazonia: indigenous and folk strategies. New York Botanical Garden, Advances in Economic Botany:7).

Balent, G. 1996. La Forêt paysanne dans l'espace rural: biodiversité, paysages, produits. Inland Northern Research Alliance (INRA), Paris, France.

Barrau, J. 1959. The sago palm and other food plants of marsh dwellers on the South Pacific Islands. Economic Botany 13:151-162. 
Barton, G.A. 2002. Empire forestry and the origins of environmentalism. Cambridge University Press, Cambridge, UK.

Bechmann, R. 1990. Trees and man: forest in the middle ages. Paragon House, New York, New York, USA.

Belcher, B., G. Michon, A. Angelsen, M. RuizPerez, and H. Asbjørnsen. 2005. The Socioeconomic conditions determining the development, persistence, and decline of forest garden systems. Economic Botany 59(3):245-253.

Bishop K. D. 1991. Community forests: implementing the concept. The Planner 77:6-10.

Bodin, Ö., M. Tengö, A. Norman, J. Lundberg, and T. Elmqvist. 2006. The value of small size: loss of forest patches and ecological thresholds in southern Madagascar. Ecological Applications 16 (2):440-451.

Boffa, J-M. 1999. Agroforestry parklands in subSaharan Africa. Food and Agriculture Organization of the United Nations (FAO) Conservation Guide 34 , Rome, Italy.

Bon, E. 2003. Common property resources at the interface of agriculture and forestry policies: before and after 1988. Tropical Ecology 44(1):121-128.

Bouamrane M., and G. Michon. 2004. Collective choices and individual decisions: the sustainability of Indonesian agroforests. Pages 251-256 in D. Babin, editor. From deforestation to forest cover dynamics and forest development, UNESCO/ CIRAD, Paris, France.

Brunois, F. 2004. La forêt peut-elle être plurielle? Définitions de la forêt des Kasua de NouvelleGuinée. Anthropologie et Sociétés 28(1):89-107.

Buttoud, G. 1995. La forêt et l'Etat en Afrique sèche et à; Madagascar. Changer de politiques forestières. Editions Karthala, Paris, France.

Byers, B. A., R. N. Cunliffe, and A. T. Hudak. 2001. Linking the conservation of culture and nature: a case study of sacred forests in Zimbabwe. Human Ecology 29(2):187-218.

Cairns, M., editor. 2007. Voices from the forest: integrating indigenous knowledge into sustainable upland farming. RFF Press, Washington D.C., USA.

Castro A. P., and E. Nielsen. 2001. Indigenous people and co-management: implications for conflict management. Environmental Science and Policy 4:229-239.

Cinotti, B., and D. Normandin. 2002. Farmers and forest property: what has happened to the "peasant forests"? Revue Forestière Française 54(4):311-328.

Colfer, C. J. P., N. Peluso, and S. C. Chin. 1997. Beyond slash and burn: building on indigenous management of Borneo's tropical rainforests. Advances in Economic Botany11.

Colfer, C. J. P., and Y. Byron 2001. People managing forests: the links between human wellbeing and sustainability. RFF, Washington, D.C., USA.

Conklin, H. C. 1954. Hanunóo agriculture: a report on an integral system of shifting cultivation in the Philippines. Food and Agriculture Organization of the United Nations (FAO) Forestry Development paper 12, Rome, Italy.

Cramer W., A. Bondeau, S. Schaphoff, W. Lucht, B. Smith, and S. Sitch. 2004. Tropical forests and the global carbon cycle: impacts of atmospheric carbon dioxide, climate change and rate of deforestation. Philosophical Transactions of the Royal Society B: Biological Sciences 359 (1443):331-343.

Depommier, D. 2003. The tree behind the forest: ecological and economic importance of traditional agroforestry systems and multiple uses of trees in India. Tropical Ecology 44(1):63-71.

Descola, P. 1987. La nature domestique: symbolisme et praxis dans l'écologie des Achuar. Editions de la Maison des Sciences de l'Homme. Man, New Series, 22(4):754-755.

Dounias, E. 1996. Sauvage ou cultivé ? La paraculture des ignames sauvages par les pygmées Baka du Cameroun. Pages 939-960 in C. M. Hladik, A. Hladik, H. Pagezy, O. F. Linares, G. J. A. Koppert, and A. Froment, editors. L'alimentation en forêt tropicale: interactions bioculturelles et perspectives de développement. UNESCO, Paris, France. 
Dounias, E. 2000. Cocoa production in Cameroon: from cash-crop plantations to agroforests. Paper presented at the International Workshop "Cultivating (in) tropical forest: intermediate systems of forest management and culture". Kræmmervika, Lofoten, Norway.

Dove, M. R. 1992. Foresters' beliefs about farmers: a priority for social science research and social forestry. Agroforestry Systems 17(11):13-41.

Dove, M. R. 1993. Smallholder rubber and swidden Agriculture in Borneo: a sustainable adaptation to the ecology and economy of the tropical forest. Economic Botany 47(2):136-147.

Dove, M. R. 1994. The transition from native forest rubbers to Hevea brasiliensis (Euphorbiaceae) among tribal smallholders in Borneo. Economic Botany 48(4): 382-396.

Dove, M.R. 1995. The theory of social forestry intervention: the state of the art in Asia. Agroforestry Systems 30(3):315-340.

Dupire, M., and J.-L. Boutiller. 1958. Le pays Adioukrou et sa palmeraie, basse Cöte-d'Ivoire. Etude socio-économique. ORSTOM, Paris, France.

Emperaire, L., editor. 1997. La forêt en jeu: l'extractivisme en Amazonie. UNESCO/ORSTOM, Paris, France.

Evans, J. 1992. Plantation forestry in the tropics: tree planting for industrial, social, environmental, and agroforestry purposes. Clarendon, London, UK.

Fairhead, J., and M. Leach. 1996. Misreading the African landscape: society and ecology in a forestsavanna mosaic. Cambridge University Press, Cambridge, UK.

Fay, C., and G. Michon. 2005. Redressing forestry hegemony: when a forestry regulatory framework is best replaced by an agrarian one. Forests,Trees and Livelihoods 15(2):193-209.

Fernandes, E. C. M., A. Oktingati, and J. Maghembe. 1984. The Chagga homegardens: a multistoried agroforestry cropping system on Mt. Kilimanjaro. Agroforestry Systems 2:73-86.
Foppes, J., and S. Ketphanh. 2000. Forest extraction or cultivation? Local solutions from Lao PDR. Paper presented at the International Workshop "Cultivating (in) tropical forest: intermediate systems of forest management and culture”. Kræmmervika, Lofoten, Norway.

Forest Trends. 2002. Strategies for strengthening community property rights over forests: lessons and opportunities for practitioners. Forest Trends, Washington D.C., USA.

de Foresta, H. 1992. Botany contribution to the understanding of smallholder rubber plantations in Indonesia: an example from Sumatra. Pages 363-368 in Proceedings of the International Symposium: Sumatera: Environment and Development: its Past, Present and Future. Seameo-Biotrop APHI/ MPI, Bogor, Indonesia.

Fried, S. G. 2000. Tropical forests forever? A contextual ecology of rattan agroforestry systems. Pages 204-233 in C. Zerner, editor. People, plants and justice: the politics of nature conservation. Columbia University Press, New York, New York, USA.

Gadgil, M., and V. D. Vartak. 1976. Sacred groves of the western Ghats in India. Economic Botany 30: $152-160$.

García-Fernández, C. 2001. Traditional management systems in tropical forest in Indonesia: ecology and silviculture. Dissertation, Universidad Complutense, Madrid, Spain.

García-Fernández, C., M. A. Casado, and M. Ruíz-Pérez. 2003. Benzoin gardens in North Sumatra, Indonesia: effects of management on tree diversity. Conservation Biology 17(3):829-836.

Gastellu, J.-M. 1980. L'arbre ne cache pas la forêt : usus fructus et abusus. Cahiers ORSTOM Série Sciences Humaines 17(3-4):279-282.

Gibson C. C., M. A. McKean, and E. Ostrom. 2000. People and forests: communities, institutions, and governance. MIT Press, Cambridge, Massachewsetts, USA.

Godelier, M. 1986 The mental and the material: thought, economy and society. Blackwell, London, UK. 
Godoy, R., and T. C. Feaw. 1989. The profitability of smallholder rattan cultivation in central Borneo. Human Ecology 16(4):397-420.

Gouyon, A., H. de Foresta, and P. Levang. 1993. Does 'jungle rubber' deserve its name? An analysis of rubber agroforestry systems in southeast Sumatra. Agroforestry Systems 22:181-206.

Guillard, J. 1999. Contribution à; l'histoire de l'aménagement dans les pays tropicaux. Revue Forestière Française 51:322-332.

Guizol, P., and C. Ndikumagenge. 2004. Forest dynamics: the case of Burundi. Pages 157-176 in D. Babin, editor. Beyond tropical deforestation. UNESCO-CIRAD, Paris, France.

Hannam K. 2000. Educating an environmental elite: the training of the Indian Forest Service. International Research in Geographical and Environmental Education 9(4):285-295.

Hartshorn, G. S. 1995. Ecological basis for sustainable development in tropical forests. Annual Review of Ecology and Systematics 26:155-175.

Higman, S., J. Mayers, S. Bass, N. Judd, and R. Nussbaum. 2005. The sustainable forestry handbook: a practical guide for tropical forest managers on implementing new standards. Earthscan, Second Edition, London, UK.

Ichikawa, M. 1998. Man and nature in central African forests. The Center for African Area Studies, Kyoto University, Kyoto, Japan.

de Jong, W. 1994. Recreating the forest: successful examples of ethno-conservation among LandDayaks in central West Kalimantan. In Proceedings of theInternational Symposium on Management of Tropical Forests in Southeast Asia, Oslo, Norway.

Juhé-Beaulaton, D., and B. Roussel. 1998. A propos de l'historicité des forêts sacrées de l'ancienne Cöte des Esclaves. Pages 353-382 in M. Chastanet, editor. Plantes et paysages d'Afrique, une histoire à; explorer. Karthala, Paris, France.

Kellman, M., and R. Tackaberry. 1997. Tropical environments: the functioning and management of tropical ecosystems. Routledge, London, UK.

Küchli, C. 1997. Forests of hope: stories of regeneration. Earthscan, London, UK.

Kumar S., and S. Kant. 2006. Organizational resistance to participatory approaches in public agencies: an analysis of forest department's resistance to community-based forest management. International Public Management Journal 9 (2):141-173.

Kusel, J. 2003. Forest communities, community forests: struggles and successes in rebuilding communities and forests. Rowman and Littlefield, .

Lamanda, N., E. Malezieux, and P. Martin. 2006. Structure and dynamics of coconut-based agroforestry systems in Melanesia: a case study from the Vanuatu Archipelago. Pages 105-121 in B. M. Kurnar and P. K. R. Nair, editors. Tropical homegardens: a time-tested example of sustainable agroforestry. Springer, The Netherlands.

Léonard, E., and M. Oswald. 1996. Une agriculture forestière sans forêt. Changements agroécologiques et innovations paysannes en Cöted'Ivoire. Nature, Sciences, Sociétés 3(4):202-216.

Lescure, J.-P. 1995. Extractivisme en Amazonie viabilité et développement. Rapport final Contrat TS3-CT91-004. ORSTOM-INPA-AARHUS University,

Levang, P., G. Michon, and H. de Foresta. 1997. Agriculture forestière ou agroforesterie? Bois et Forêts des Tropiques 251(1):29-42.

Long, A. J., and P. K. R. Nair. 1999. Trees outside forests: agro-, community, and urban forestry. New Forests 17(1-3):145-174.

Lynch, O., and K. Talbot. 1995. Balancing acts: community-based forest management and national law in Asia and the Pacific. World Resources Institute, Washington D.C., USA.

Mayers, J., and S. Bass. 2004. Policy that works for forests and people: real prospects for governance and livelihoods. Earthscan-International Institute for Environment and Development, London, UK.

Michon, G. 2005. Domesticating forests: how farmers manage forest resources. IRD/CIFOR/ ICRAF, Bogor, Indonesia.

Michon, G., and H. de Foresta. 1995. The 
Indonesian agroforest model: fForest resource management and biodiversity conservation. P. Halliday and D. A. Gilmour, Editors. in Conserving biodiversity outside protected areas: the role of traditional agro-ecosystems. IUCN, Gland, Switzerland.

Michon, G., and H. de Foresta. 1997. Agroforests: pre-domestication of forest trees or true domestication of forest ecosystems? Netherlands Journal of Agricultural Science 45:451-462.

Michon, G., and H. de Foresta. 1999. Agroforests: incorporating a forest vision in agroforestry. Pages 381-406 in L. E. Buck, J. Lassoie and E. C. M. Fernandes, editors. Agroforestry in sustainable agricultural systems. CRC Press, Washington D.C., USA

Michon, G., H. de Foresta, A. Kusworo, and P. Levang. 2000. The Damar agro-forests of Krui, Indonesia: justice for forest farmers. Pages 159-203 in C. Zerner, editor. People, plants and justice: the politics of nature conservation. Columbia University Press, USA.

Mittermeier, R. A., N. Myers, and C. GoettschMittermeier. 2000. Hotspots: Earth's biologically richest and most endangered ecoregions. Conservation International, , USA.

Momberg, F. 1993. Indigenous knowledge systems: potentials for social forestry development: resource management of Land-Dayaks in West Kalimantan. Technische Universität Berlin, Berlin, Germany.

Niesten, E. 2002. Designing a carbon market that protects forests in developing countries. Philosophical Transactions of the Royal Society A: Mathematical, Physical and Engineering Sciences 360(1797):1875-1888.

Noble, I. R., and R. Dirzo. 1997. Forests as human dominated ecosystems. Science 277(5325):522-525.

Padoch, C., and C. Peters. 1993. Managed forest gardens in West Kalimantan, Indonesia. Pages 167-176 in C. S. Potter, J. I. Cohen, and D. Janczewski, editors. Perspectives on biodiversity: case studies of genetic resource conservation and development. AAAS, Waldorf, Maryland, USA.

Pancel, L., editor. 1993. Tropical forestry handbook. Volumes 1 and 2. Springer-Verlag, New York, New York, USA.
Pardé, J. 1986. Naissance et développement d'une sylviculture européenne commune. Annales de Gembloux 2:87-110.

Parikesit, K., T. A. Tsunekawa, and O. S. Abdoellah. 2003. Kebon tatangkalan: a disappearing agroforest in the Upper Citarum Watershed, West Java, Indonesia. Agroforestry Systems 63:171-182

Pélissier, P. 1964. Types et genèse des paysages de parc élaborés par l'agriculture africaine. Page 161 in Proceedings of the 20th International Congress of Geography, Londres,

Peluso, N. L. 1996. Fruit trees and family trees in an Indonesian rainforest: property rights, ethics of access, and environmental change. Comparative Studies in Society and History 38(3):510-548.

Posey, D. A. 1985. Indigenous management of tropical forest ecosystems: the case of the Kayapo Indians of the Brazilian Amazon. Agroforestry Systems 3(2):139-158.

Potter, L. 2001. Agricultural intensification in Indonesia: outside pressures and indigenous strategies. Asia-Pacific Viewpoint 42 (2/3):305-324.

Potter, L. 2004. Can Indonesia's complex agroforests survive globalisation and decentralisation? a study in Sanggau district, West Kalimantan? Paper presented to the 15th Biennial Conference of the Asian Studies Association of Australia in Canberra 29 June-2 July 2004.

Pretzsch, J. 2005. Forest related rural livelihood strategies in national and global development. Forests, Trees and Livelihoods 15(2):115-127.

Raison, J.-P. 1988. Les parcs en Afrique : état des connaissances, perspectives de recherches. Document de travail, Centre d'Etudes Africaines, EHESS, Paris, France.

Repetto, R., and M. Gillis, editors. 1988. Public policies and the misuse of forest resources. Cambridge University Press, Cambridge, UK.

Ribot, J. 2001. Science, use rights and exclusion: a history of forestry in Francophone West Africa. Drylands Issue Paper, IIED.

Rietbergen, S. 2001. The history and impact of 
forest management. Pages 1-25 in J. Evans, editor. The forests handbook, Volume 2: applying forest science for sustainable management. Blackwell,

Rougerie, G. 1957. Les pays Agni du Sud-Est de la Cöte-d'Ivoire forestière. Etudes éburnéennes 7:7-213.

Ruf, F. 2001. Tree crops as deforestation and reforestation agents: the case of cocoa in Cöte d'Ivoire and Sulawesi. Pages 291-315 in A. Angelsen and D. Kaimowitz, editors. Agricultural technologies in tropical deforestation. CABI, Wallingford,

Salafsky, N. 1994. Forest gardens in the Gunung Palung region of West Kalimantan, Indonesia. Agroforestry Systems 28:237-268.

Sandbukt, O. 1982. Perceiving the Sumatran Kubus. Annual Newsletter of the Scandinavian Institute of Asian Studies.

Sardjono, M. A. 1992. Lembo culture in East Kalimantan: A model for the development of agroforestry land-use in the humid. GFG-Report 21:45-62.

Schlaifer, M. 1997. Des "cités de la forêt". Mieux comprendre les représentations pour justifier l'action. Dossier de l'Environnement, Inland Northwest Research Alliance (INRA) 15:109-129.

Schroth, G., C. A. Harvey, and G. Vincent. $2004 a$. Complex agroforests: their structure, diversity and potential role in landscape conservation. Pages 227-260 in G. Schroth, G. A. B. da Fonseca, C. A. Harvey, C. Gascon, H. L. Vasconcelos, and A.-M. N. Izac, editors. Agroforestry and biodiversity conservation in tropical landscapes. Island Press, Washington D.C., USA.

Schroth, G., V. H. F. Moraes, and M. S. S. da Mota. 2004b. Increasing the profitability of traditional, planted rubber agroforests at the Tapajós river, Brazilian Amazon. Agriculture, Ecosystems and Environments 102(3):319-339.

Scott, J. C. 1998. Seeing like a state: how certain schemes to improve the human condition have failed. Yale University Press, New Haven, Connecticut, USA.

Sekhar, N. U., and I. Jørgensen. 2003. Social forestry in South Asia: myths and realities. Noragric
Working Paper Number 30. Noragric, Agricultural University of Norway, Ås Norway.

Seignobos, C. 1982. Végétations anthropiques dans la zone soudano-sahélienne : la problématique des parcs. Revue de géographie du Cameroun 3(1):1-23.

Seibert, B. 1989. Indigenous fruit trees of Kalimantan in traditional culture. Pages 299-300 in J. S. Siemonsma and N. Wulijarni-Soejipto, editors. First PROSEA International Symposium on Plant Resources of South-East Asia. Pudoc, Wageningen, Jakarta, Indonesia.

Senbeta F., and M. Denich. 2006. Effects of wild coffee management on species diversity in the Afromontane rainforests of Ethiopia. Forest Ecology and Management 232(1-3):68-74.

Sheperd, G., E. Shanks, and M. Hobley. 1993. Management of tropical and subtropical dry forests. Pages 107-136 in S. Rietbergen, editor. The Earthscan reader in tropical forestry. Earthscan, London, UK.

Sherr, S. J., A. White, and D. Kaimowitz. 2001. Making markets eork for gorest communities. Forest Trends, Washington D.C., USA.

Smouts, M.-C.2003. Tropical forests, international jungle: the underside of global ecopolitics. Palgrave MacMillan, New York, New York, USA.

Somarriba, E., C. A. Harvey, M. Samper, F. Anthony, J. Gonzalez, C. Staver, and R. A. Rice. 2004. Biodiversity conservation in neotropical coffee (Coffea arabica) plantations. Pages 198-226 in G. Schroth, G. A. B. da Fonseca, C. A. Harvey, C. Gascon, H. L. Vasconcelos, and A.-M. N. Izac, editors. Agroforestry and biodiversity conservation in tropical landscapes. Island Press, Washington D. C., USA.

Sundawati, L. 1993. The Dayak garden systems in Sanggau, West Kalimantan: an agroforestry model. Thesis, Georg-August University, Göttingen, Germany.

Suyanto, T. P. Tomich, and K. Otsuka. 2001. Land tenure and farm management efficiency: the case of smallholder rubber production in customary land areas in Sumatra. Agroforestry Systems $\mathbf{5 2}$ (2):145-160. 
Temu, A. B., D. Okali, and B. Bishaw. 2006. Forestry education, training and professional development in Africa. International Forestry Review 8(1):118-125.

Torquebiau, E. 1984. Man-made dipterocarp forest in Sumatra. Agroforestry Systems 2:103-127.

Valeix, J. 1999. Quelle démarche d'aménagement retenir en forêt tropicale humide? Revue Forestière Française 51:333-346.

Verdeaux, F., editor. 1999. La forêt-monde en question: recomposition des rapports des sociétés à; la forêt dans les pays du sud. Autrepart: vahiers de sciences humaines 9. Editions de l'aube-IRD, Bondy, France.

Verdeaux, F. 2003. De la forêt en commun à la forêt domestique: deux cas contrastés de réappropriation forestière en Cöte-d'Ivoire et Tanzanie. Bois et Forêts des Tropiques 278(4):51-63.

Watanabe, H., K. Kawai, S. Takeda, M. Morita, K. Abe, S. Khamyong, and C. Khemnark. 1990. Tea cultivation in the natural forest in northern Thailand: a case study on rational forest management. Thailand Journal of Forestry 9:219-226.

Weber, J., J. M. Betsch, and P. Cury. 1990. A l'interface hommes-nature: les ressources renouvelables. Pages 39-50 in P. E. Piren, editor. Actes du colloque recherche et environnement, Strasbourg, France.

Westoby, J. C. 1979. Forest industries for socioeconomic development. Commonwealth Forestry Review 58(2):107-116.

Wiersum, K. F. 2004. Forest gardens as an 'intermediate' land-use system in the nature-culture continuum: characteristics and future potential. Agroforestry Systems 61:123-134.

Wollenberg, E. 2001. Social learning in community forests. Center for International Forestry Research (CIFOR) East-West Center, Hawai, USA.

Wormald, T. J. 1992. Mixed and pure forest plantations in the tropics and the subtropics. Food and Agriculture Organization of the United Nations (FAO), Rome, Italy. 